\title{
DETERMINATION OF BIOGENIC AMINES AND ENDOTOXIN IN SQUID, MUSKY OCTOPUS, NORWAY LOBSTER, AND MUSSEL STORED AT ROOM TEMPERATURE
}

\author{
Ljerka PRESTER ${ }^{1}$, Tatjana ORCT ${ }^{1}$, Jelena MACAN ${ }^{1}$, Jelena VUKUŠIĆ ${ }^{2}$, and Dubravka KIPČIĆ ${ }^{2}$ \\ Institute for Medical Research and Occupational Health ${ }^{l}$, Croatian National Institute of Public Health ${ }^{2}$, \\ Zagreb, Croatia
}

Received in May 2010

Accepted in October 2010

\begin{abstract}
Little research has been published on the indicators of spoilage in Mediterranean molluscan shellfish and crustaceans. Thus is why we studied changes in the concentrations of endotoxin and four biogenic amines (histamine, putrescine, tyramine and cadaverine) in European common squid (Loligo subulata, Lamarck, 1798), musky octopus (Eledone moschata, Lamarck, 1798), Norway lobster (Nephrops norvegicus, Linnaeus, 1758), and mussel (Mytilus galloprovincialis, Lamarck, 1819) from the Adriatic Sea stored at room temperature for $24 \mathrm{~h}$. Endotoxin load in fresh squid, Norway lobster, and mussel $\left(<1 \mathrm{EU} \mathrm{mg}^{-1}\right)$ indicated good microbiological quality of raw samples. Biogenic amine index (as the sum of histamine, putrescine, tyramine, and cadaverine) correlated well with endotoxin load in squid ( $\mathrm{r}=0.978, \mathrm{p}<0.001)$ and musky octopus $(\mathrm{r}=0.874, \mathrm{p}<0.01)$. A good correlation was also found between endotoxin and putrescine in Norway lobster $(\mathrm{r}=0.777, \mathrm{p}<0.05)$. The highest endotoxin load was found in decomposed mussels and was associated with histamine alone. In conclusion, increase in biogenic amine levels is species-specific. Endotoxin analysis could be used for rapid assessment of microbiological quality of cephalopods and shellfish.
\end{abstract}

KEY WORDS: histamine, tyramine, putrescine, cadaverine, cephalopods, crustaceans, bivalve shellfish, food safety, spoilage, Loligo subulata, Eledone moschata, Nephrops norvegicus, Mytilus galloprovincialis

Cephalopods (squid, octopus, and cuttlefish), crustaceans (shrimp, Norway lobster), and bivalve molluscs (mussels) have been an important seafood for many people worldwide, and their consumption has been increasing in many countries that are not traditionally shellfish consumers. Like many fish species, shellfish are also prone to spoiling quickly; however, indicators of decomposition in cephalopods and shellfish are not as well established as for fin fish. Histamine, putrescine, cadaverine, and tyramine are commonly used as chemical indicators of fish decomposition. They are usually formed through bacterial decarboxylation of specific precursor free amino acids (1). Among amines, histamine and tyramine can initiate various pharmacological reactions including rash, urticaria, nausea, vomiting, diarrhoea, tingling, itching of the skin, and tachycardia (2). Polyamines and tyramine can enhance the toxic effect of histamine by interfering with histaminedetoxifying enzymes $(2,3)$. These biogenic amines may be implicated in the formation of carcinogenic nitrosamine (2). Generally, histamine level in decomposed cephalopods and shellfish is low and poisoning by histamine is not usually related to their 
consumption (4). Putrescine, cadaverine, and agmatine have been proposed as freshness indicators in shrimp and squid, as they were the only amines detected before the initial decomposition $(5,6)$.

Gram-negative bacteria are the predominant amine-forming bacteria in fish, cephalopods and shellfish (7-11). Endotoxins are integral components of the outer membrane of Gram-negative bacteria, which are typically released upon bacterial lysis and during multiplication. The Limulus amoebocyte lysate (LAL) assay is a highly sensitive and standard test for endotoxin measurement in various environments. This assay was applied in several studies as a quick, alternative method for microbiological testing and hygiene control of fish $(12,13)$ and meat (14). Several studies demonstrated a high correlation between the LAL test and the microbial quality of the products $(12,14)$. Currently, this test has not been applied in testing the freshness/spoilage of non-fin fish. The reference method for amine detection in fish is high-performance liquid chromatography (HPLC) (15), but it requires extensive sample preparation and is expensive to perform. Some investigators have proposed thin-layer chromatography (TLC) as an alternative in preliminary screening for biogenic amines in fish and marine products $(16,17)$, and we used it in this study.

A high level of protection of public health is one of the fundamental objectives of food law. Spoilage of marine organisms due to post-harvest handling and storage at elevated temperature is one of the greatest problems affecting the fish industry all over the world. Despite the fact that cephalopods and shellfish are important food source, to our knowledge, spoilage markers in non-fin fish species have not been as extensively studied as in fin fish.

Therefore, the objective of this study was to evaluate the reliability of main biogenic amines as chemical indicators of decomposition in European common squid, musky octopus, Norway lobster, and mussel stored at room temperature $(22 \pm 1)^{\circ} \mathrm{C}$ for 24 h. The secondary objective was to test the LAL assay in detecting endotoxin levels in cephalopods and shellfish as a means to monitor microbial loads.

\section{MATERIALS AND METHODS}

\section{Seafood samples}

European common squid (Loligo subulata, Lamarck, 1798), musky octopus (Eledone moschata,
Lamarck, 1798) Norway lobster (Nephrops norvegicus, Linnaeus, 1758), and Mediterranean blue mussels (Mytilus galloprovincialis, Lamarck, 1819) were caught along the Croatian Adriatic coast between Zadar and Mali Ston in 2007. They were kept in ice boxes and purchased at the central fish market in Zagreb, 36 $\mathrm{h}$ to $48 \mathrm{~h}$ later. All shellfish were transported to the laboratory in sterile plastic bags surrounded by crushed ice. Upon arrival to the lab within one hour from the purchase, a total of nine squids (average weight 8.4 $\mathrm{g}$ ), and nine Norway lobsters (average length $15 \mathrm{~cm}$ ) were divided in three sterile plastic plates with three samples each. Three musky octopuses (average weight $207 \mathrm{~g}$ ) were placed individually in three sterile plastic plates. A total of forty-five mussels (average length $7.5 \mathrm{~cm}$ in shell length) were divided in three sterile plastic plates with fifteen mussels each for analysis. Samples of muscle were collected on hours 0,12 , and 24 of decomposition at $(22 \pm 1){ }^{\circ} \mathrm{C}$. All samples were taken randomly using sterile knives (to avoid post-harvesting contamination) in portions of about $5 \mathrm{~g}$ for amine and $1 \mathrm{~g}$ for endotoxin analysis, placed in separate aseptic bags, and stored at $-20{ }^{\circ} \mathrm{C}$ until analysis, which took place within a month.

\section{Biogenic amine analysis}

The concentrations of histamine, tyramine, putrescine, and cadaverine were determined using thin-layer chromatography (TLC) according to Lieber and Taylor (18), with slight modifications. Five grams of shellfish muscle were extracted in $10 \mathrm{~mL}$ of methanol (Kemika, Zagreb, Croatia), homogenised, and centrifuged. For sample fractionation, aliquots of supernatants were applied to pre-coated silica plates SIL G-25 UV ${ }_{254}$ (Macherey-Nagel, Duren, Germany). A series of diluted standard solutions were prepared from standard stock solutions (Merck, Darmstadt, Germany). Details have been described in our earlier paper (13). All analyses were done in triplicate. The precision for each amine (expressed as coefficient of variation, CV) was lower than $10 \%$. Average recoveries were between $85 \%$ and $110 \%$. The limit of detection was $10 \mathrm{mg} \mathrm{kg}^{-1}$ for histamine and tyramine and $5 \mathrm{mg} \mathrm{kg}^{-1}$ for putrescine and cadaverine.

\section{Endotoxin analysis}

Endotoxin was measured using the chromogenic LAL endpoint assay, which is based on the activation of a clotting enzyme in the lysate (14). The LAL test was purchased from Charles River Endosafe (Charleston, SC, USA). It uses the following reagents: 
lyophilised LAL reagent-derived from the blood of a horseshoe crab, endotoxin standard (E. coli 0111:B4), S-2423 chromogenic substrate, Tris buffer solution, and LAL reagent water.

Samples of shellfish $(100 \mathrm{mg})$ were extracted into a pyrogen-free test tube with $5 \mathrm{~mL}$ of endotoxinfree water (Endosafe, lot no. 99732065) containing $0.05 \%$ Tween-20 (Merck, Darmstad, Germany). All extracts were vortexed and centrifuged at $2500 \mathrm{rpm}$, and 2-mL aliquots of supernatants transferred to pyrogen-free tubes and left at $75^{\circ} \mathrm{C}$ for $20 \mathrm{~min}$ to avoid any possible interference. The extracts were then serially diluted $(1: 400$ to $1: 500,000)$ in LAL water to achieve a linear working concentration for the LAL assay. Standard curves were made by reconstituting the endotoxin standard with LAL reagent water. The potency of endotoxin standard was 24 endotoxin units per nanogram (EU ng ${ }^{-1}$ ) (product number ET 84092). The endotoxin calibration curve ranged from $0.015 \mathrm{EU}$ $\mathrm{mL}^{-1}$ to $0.12 \mathrm{EU} \mathrm{mL}^{-1}$. Negative and positive controls were included for every set of samples (13). In brief, $50 \mu \mathrm{L}$ of extracts, endotoxin standards, controls, and blanks were added to endotoxin-free microtitre plates (Greiner Labortechnik, Frickenhausen, Germany). Following a 5-min incubation, $50 \mu \mathrm{L}$ of LAL reagent was added per well and incubated at $37^{\circ} \mathrm{C}$ for another $15 \mathrm{~min}$. Substrate-buffer solution $(100 \mu \mathrm{L})$ was added to all wells and after 8 min colour reaction was stopped by adding $20 \%$ acetic acid $(100 \mu \mathrm{L})$. The absorbance at $405 \mathrm{~nm}$ was measured using a Personal Lab microplate reader (IASON, Graz, Austria). Each sample was measured in duplicate. The results were expressed as endotoxin units per milligram $\left(\mathrm{EU} \mathrm{mg}^{-1}\right)$. The median coefficient of variation was $12.3 \%$, and recovery varied from $93 \%$ to $109 \%$.

\section{Statistical analysis}

The results are expressed as mean \pm standard deviation (SD). For statistical analysis we used Statistica software, version 9.0 (StatSoft, Tulsa, OK, USA). Pearson's correlation coefficient was obtained to estimate the correlation between endotoxin and biogenic amine content in the nine samples obtained for each shellfish species. Samples with biogenic amines below the detection limit were given a value of half the detection limit. The value of $p<0.05$ was considered statistically significant unless indicated otherwise.

\section{RESULTS AND DISCUSSION}

\section{Biogenic amines in cephalopods}

Even though the overall biogenic amine content increased in squid and musky octopus decomposed at $22^{\circ} \mathrm{C}$, the time-course of amine production differed. At baseline (hour 0), histamine and putrescine concentrations in whole European common squid were $(15.3 \pm 1.7) \mathrm{mg} \mathrm{kg}^{-1}$ and $(8.3 \pm 4.7) \mathrm{mg} \mathrm{kg}^{-1}$, respectively, and other biogenic amines were not detected. There was a significant correlation between the storage time and amine content (histamine, putrescine, tyramine, and cadaverine) in squid samples (Pearson's $\mathrm{r}$ ranged from 0.669 to $0.820, \mathrm{p}<0.05$ ). At hour 12, histamine, putrescine, and tyramine in squid increased to $(19.7 \pm 0.5) \mathrm{mg} \mathrm{kg}^{-1},(39.3 \pm 0.9) \mathrm{mg}$ $\mathrm{kg}^{-1}$, and (15.3 \pm 1.7$) \mathrm{mg} \mathrm{kg}^{-1}$, respectively (Figure 1a). As decomposition in squid progressed to hour 24, putrescine and tyramine levels increased exponentially and reached (209.3 \pm 82.0$) \mathrm{mg} \mathrm{kg}^{-1}$ and (229 \pm 72.9$) \mathrm{mg}$
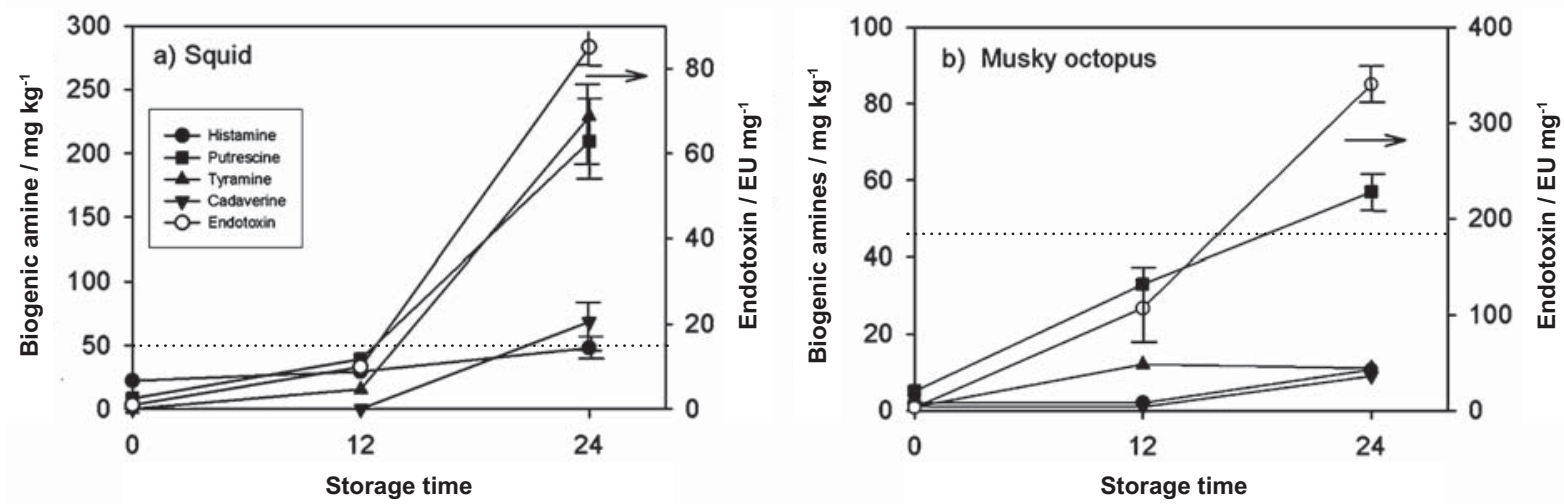

Figure 1 Changes in histamine, putrescine, tyramine, cadaverine, and endotoxin levels in European common squid and musky octopus stored at $22^{\circ} \mathrm{C}$. Each point represents the mean value of three shellish samples. Where bars are not visible, determinations are within the size of the symbols. The dotted line shows the limit of acceptance for histamine. 
$\mathrm{kg}^{-1}$, respectively. On the other hand, the increase in histamine and cadaverine was much slower than in putrescine and tyramine. Cadaverine was detected only at the advanced stage of squid decomposition [(68.3 \pm 20.9$\left.) \mathrm{mg} \mathrm{kg}^{-1}\right]$. In contrast, histamine detected at the initial stage slowly increased to $(32 \pm 12.3) \mathrm{mg}$ $\mathrm{kg}^{-1}$ by the end of storage. The European Community has set the maximum average histamine level for scombroid and scombroid-like fish to $100 \mathrm{mg} \mathrm{kg}^{-1}(15)$, whereas the US Food and Drug Administration has set this level to $50 \mathrm{mg} \mathrm{kg}^{-1}$ (19). Histamine and tyramine are considered as anti-nutritional compounds and pose health risk to sensitive individuals. Currently there is no legal limit for biogenic amines in any cephalopod species. In our study, histamine did not exceed either of the above limit in decomposed squid, but tyramine rose above the lower safety level $\left(100 \mathrm{mg} \mathrm{kg}^{-1}\right)$ for human consumption (20). Putrescine is the major amine produced in a squid decomposing at a relatively high temperature, which is in agreement with Yamanaka et al. (21), who found putrescine at the early stage of decomposition of common squid (Todarodes pacificus) stored at $0{ }^{\circ} \mathrm{C}$ and $15{ }^{\circ} \mathrm{C}$. Paarup et al. (5) suggest that rapid putrescine formation in decomposed squid is owed to early bacterial conversion of agmatine, a biogenic amine that otherwise indicates freshness. Although putrescine has no adverse health effects, high putrescine levels in decomposed squid could potentiate the toxic effects of histamine and tyramine $(1,3)$.

Figure $1 \mathrm{~b}$ shows the accumulation profile of biogenic amines in whole musky octopus decomposed at $22{ }^{\circ} \mathrm{C}$. The baseline putrescine content was

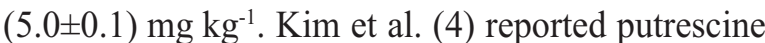
content of (2.4 \pm 3.3$) \mathrm{mg} \mathrm{kg}^{-1}$ in fresh Japanese octopus (Octopus minor). Other biogenic amines were not detected at this stage. At hours 12 and 24, putrescine increased significantly to $(33 \pm 2.9) \mathrm{mg} \mathrm{kg}^{-1}$ and $(56.7 \pm 13.9) \mathrm{mg} \mathrm{kg}^{-1}(\mathrm{r}=0.833, \mathrm{p}<0.01)$, respectively. In contrast to putrescine, the increase in other biogenic amines was much lower $\left(5.0 \mathrm{mg} \mathrm{kg}^{-1}\right.$ to $\left.10.0 \mathrm{mg} \mathrm{kg}^{-1}\right)$ probably due to low free amino-acids which are the precursors of biogenic amines (22). Yet, the Eledone species seems to spoil quickly if not stored properly, as shown by the high bacterial endotoxin load (Figure $1 b)$.

\section{Biogenic amines in Norway lobster}

In our study (Figure $2 \mathrm{a}$ ), the baseline putrescine content of $(7.3 \pm 0.5) \mathrm{mg} \mathrm{kg}^{-1}$ in lobster muscle was higher than in some other crustaceans such as Humpback shrimp (Pandalus hypsinotus)
(1.3 \pm 2.0$) \mathrm{mg} \mathrm{kg}^{-1}(4)$ and penaeid shrimp $\left(1 \mathrm{mg} \mathrm{kg}^{-1}\right)$ (6). At hours 12 and 24, putrescine slowly increased to $(10 \pm 2.8) \mathrm{mg} \mathrm{kg}^{-1}$ and $(25.3 \pm 2.5) \mathrm{mg} \mathrm{kg}^{-1}$, respectively $(\mathrm{r}=0.777, \mathrm{p}=0.0138)$. In contrast to putrescine, other amines (histamine, tyramine, and cadaverine) were not detected in lobster muscle at any stage. These findings are generally in agreement with the observations of Mietz and Karmas (23), who found early putrescine formation in Norway lobster stored in ice. Benner et al. (6) have suggested putrescine as the best indicator of decomposition for penaeid shrimp stored at a wide range of temperatures $\left(0{ }^{\circ} \mathrm{C}\right.$ to $\left.36^{\circ} \mathrm{C}\right)$ and proposed the putrescine level of $3 \mathrm{mg} \mathrm{kg}^{-1}$ as a threshold for human consumption. In contrast to our study, increase in putrescine was accompanied by increase in cadaverine in decomposed pink shrimp (Litopenaeus brasiliensis) (6), Indian shrimp (Parapenaeopis stylifera) (24), and white prawn (25).

Our study has shown that despite the storage at elevated temperature, histamine concentration in Norway lobster remained below the detection limit. This suggests that Norway lobster could be suitable for consumers with histamine intolerance $(26,27)$.

\section{Biogenic amines in Mediterranean blue mussel}

The baseline levels of all biogenic amines in mussel samples were below the detection limit $\left(<5 \mathrm{mg} \mathrm{kg}^{-1}\right.$ to $10 \mathrm{mg} \mathrm{kg}^{-1}$, Figure 2b). Our finding for histamine is similar to Aureswald et al. (28). At hours 12 and 24, histamine rapidly increased to $(48.3 \pm 6.2) \mathrm{mg} \mathrm{kg}^{-1}$ and (76.7 \pm 17.0$) \mathrm{mg} \mathrm{kg}^{-1}$, respectively. On the other hand, putrescine, tyramine, and cadaverine levels remained below the detection limit. These results suggest that histamine is the best indicator of decomposition for mussels stored at elevated temperature. In contrast, Erkan (29) reported a significant increase in putrescine levels in blue mussel decomposed at $4{ }^{\circ} \mathrm{C}$. Mackie et al. (30) confirmed very low histamine and considerable putrescine, cadaverine, and agmatine production in the muscle of another decomposing molluscan shellfish, Atlantic scallop (Pecten maximus) at $0{ }^{\circ} \mathrm{C}$. The reader may note that in both cases storage temperature substantially differed from ours. This however does not explain the differences in findings, and we believe that only future studies will find the right indicators of decomposition for mussels and other bivalve molluscan shellfish.

What our study has clearly shown, however, is that biogenic amine production varies extremely between species. Despite storage at high temperature, histamine level in our samples never reached maximum limits 

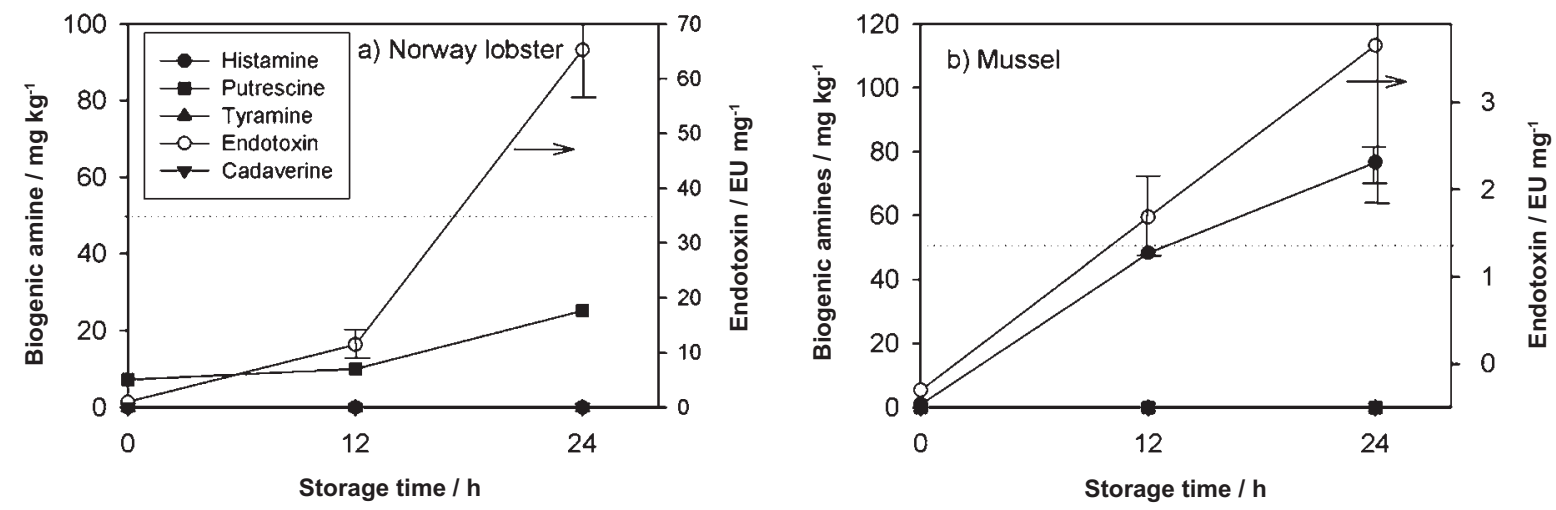

Figure 2 Changes in histamine, putrescine, tyramine, cadaverine, and endotoxin levels in Norway lobster and mussels stored at $22{ }^{\circ} \mathrm{C}$. Each point represents the mean value of three shellfish samples. Where bars are not visible, determinations are within the size of the symbols. The dotted line shows the limit of acceptance for histamine.

reported for mackerel (13), sardines, anchovies (31), and tuna (32) stored at $22{ }^{\circ} \mathrm{C}$ to $25^{\circ} \mathrm{C}$. In addition, the time-course of amine formation in squid, musky octopus, Norway lobster, and mussels differs from the one in histidine-poor fish such as hake (13).

\section{Biogenic amine index in cephalopods}

Many studies indicate that biogenic amine index (BAI) could be a better indicator of fish freshness/ spoilage than simple histamine analysis (33-38). BAI is usually determined as a sum of histamine, putrescine, tyramine, and cadaverine contents for scombroid fish species (33). Our mean baseline BAI in squid and musky octopus was $23.3 \mathrm{mg} \mathrm{kg}^{-1}$ and $5.0 \mathrm{mg} \mathrm{kg}^{-1}$, respectively (Table 1). At hour 12 , BAI in squid increased to $66.3 \mathrm{mg} \mathrm{kg}^{-1}$ and in musky octopus to $44.7 \mathrm{mg} \mathrm{kg}^{-1}$. This increase with storage time $(p<0.01)$ suggests that BAI may be a reliable indicator of spoilage of squid and musky octopus. While it was much lower in both our cephalopods than we reported earlier in Atlantic mackerel and sardine (histidine-rich fish) stored at $22^{\circ} \mathrm{C}$ for $12 \mathrm{~h}$ (13), it was much higher than we reported in hake (histidine-poor fish) in the same study. Currently, there is no BAI limit for cephalopods.

\section{Endotoxin level in cephalopods and shellfish}

Similar to bacterial load, high endotoxin levels in food usually reflect improper storage conditions and post-processing contamination. According to the Commission of the European Communities (15), foodstuffs including marine organisms should not contain micro-organisms or their toxins in quantities that present an unacceptable risk for human health.

Table 1 Biogenic amine index (BAI) in some fish and shellfish species from the hygienic point of view.

\begin{tabular}{lcc}
\hline Species & Biogenic amines & BAI $/ \mathbf{~ m ~ k g ~}^{-1}$ \\
\hline Tuna (33) & PU+TY+HI+CA & $<50$ \\
\hline Anchovies (34) & PU+TY+HI+CA & $<15$ \\
\hline Carp (35) & PU+CA & $<20$ \\
\hline Rainbow trout (36) & PU & 13 to 14 \\
\hline Squid (37) & CA & $<10$ \\
\hline Squid & PU+TY+HI+CA & $<23^{\mathrm{b}}$ \\
\hline Musky octopus & PU+TY+HI+CA & $<5^{\text {b }}$ \\
\hline Penaeid shrimp (6) & PU & $<3$ \\
\hline Norway lobster & PU & $<7^{\mathrm{b}}$ \\
\hline Mussel (29) & PU & $<60$ \\
\hline Hake (38) & PU+TY+HI+CA & $<9.3$ \\
\hline
\end{tabular}

a PU: putrescine; TY: tyramine; HI: histamine; CA: cadaverine

${ }^{b}$ this study 
Endotoxin content of $<1 \mathrm{EU} \mathrm{mg}^{-1}\left(\approx 100 \mathrm{ng} \mathrm{g}^{-1}\right)$ reported in a number of fresh fish species has been recommended as the limit of acceptability $(12,13)$. Our baseline endotoxin level kept within this limit in squid, Norway lobster, and mussel (range: 0.51 $\mathrm{EU} \mathrm{mg}{ }^{-1}$ to $0.94 \mathrm{EU} \mathrm{mg}^{-1}$ ) but exceeded it in musky octopus (3.0 \pm 0.9$) \mathrm{EU} \mathrm{mg}^{-1}$. The corresponding BAI of $>5.0 \mathrm{mg} \mathrm{kg}^{-1}$ could indicate initial decomposition (Table 1). As expected, the correlation between storage time and endotoxin level was high $(\mathrm{r}=0.749$ to $0.949, \mathrm{p}<0.05$ ). At hour 12 , endotoxin in squid and Norway lobster increased to (9.9 \pm 5.9$) \mathrm{EU}$ $\mathrm{mg}^{-1}$ and (11.5 \pm 6.4$) \mathrm{EU} \mathrm{mg}^{-1}$, respectively, and in mussels and musky octopus it was considerably higher (48.3 \pm 15.1$) \mathrm{EU} \mathrm{mg}^{-1}$ and $(106.7 \pm 41.3) \mathrm{EU}$ $\mathrm{mg}^{-1}$, respectively (Figures 1 and 2). Endotoxin accumulated as decomposition progressed; at hour 24 , entered the logarithmic phase and increased to (4477 \pm 1874$) \mathrm{EU} \mathrm{mg}^{-1}$ in mussels, followed by musky octopus $(340 \pm 41.5) \mathrm{EU} \mathrm{mg}^{-1}$, squid (84.9 \pm 39.6$) \mathrm{EU}$ $\mathrm{mg} \mathrm{kg}^{-1}$, and Norway lobster $(65.3 \pm 35.8) \mathrm{EU} \mathrm{mg}$ $\mathrm{kg}^{-1}(\mathrm{r}=0.749$ to $0.949, \mathrm{p}<0.01)$.

These results show that endotoxin levels vary widely across shellfish species (the difference can be as high as 70-fold) and that endotoxin could be a valuable indicator of freshness/spoilage of molluscs, and crustaceans as it provides additional data on bacteria load without having to cultivate bacteria for analysis. To our knowledge, endotoxin has not yet been investigated in fresh and decomposed molluscan shellfish and crustaceans. The use of endotoxin as hygiene control measure for these marine organisms needs further investigation.

We found high correlations between endotoxin and some biogenic amines in squid, musky octopus, and Norway lobster (Table 2). They were also high between endotoxin and BAIs in squid $(\mathrm{r}=0.978, \mathrm{p}<0.001)$ and musky octopus $(\mathrm{r}=0.874, \mathrm{p}<0.01)$, which suggests that BAI can be a reliable indicator of decomposition for the two species. In Norway lobster the correlation was high between endotoxin and putrescine $(\mathrm{r}=0.777$, $\mathrm{p}=0.0138$ ), but none was found between endotoxin and the most toxicologically important amines histamine and tyramine. This highlights putrescine as a reliable indicator of decomposition for Norway lobster, just as it is for shrimp (6). In mussels, endotoxin correlated with histamine, but not significantly $(\mathrm{r}=0.568$, $\mathrm{p}=0.111)$.

\section{CONCLUSION}

This study has provided new information on the spoilage markers of some cephalopods and shellfish. Our results indicate that deterioration in the quality of the four shellfish is species-specific and highly temperature and time-dependent. Despite storage at elevated temperature, histamine levels in squid, musky octopus, Norway lobster, and mussel did not exceed limits, even when endotoxin levels were unacceptably high. This calls for alternative markers such as BAI, which could be used for monitoring spoilage in squid and musky octopus, while putrescine could be used for Norway lobster. The LAL assay can be used for rapid assessment of microbiological contamination of shellfish. The role of bacterial endotoxin in the pathophysiology of histamine fish poisoning has not been investigated.

\section{REFERENCES}

1. Lehane L, Olley J. Histamine fish poisoning revisited. Int $\mathrm{J}$ Food Microbiol 2000;58:1-37.

Table 2 Pearson's correlation coefficient (r) between endotoxin $\left(E U \mathrm{mg}^{-1}\right)$ and biogenic amines $\left(\mathrm{mg} \mathrm{kg}^{-1}\right)$ and endotoxin and biogenic amine index (BAI) in cephalopods and shellfish decomposed at $22{ }^{\circ} \mathrm{C}$.

\begin{tabular}{lcccc}
\hline \multirow{2}{*}{ Biogenic amine } & \multicolumn{4}{c}{ Correlation coefficient (r) } \\
\cline { 2 - 5 } & Squid & Musky octopus & Norway lobster & Mussel \\
\hline Histamine & $0.904^{\mathrm{a}}$ & $0.877^{\mathrm{b}}$ & - & $0.568^{\mathrm{ns}}$ \\
Putrescine & $0.986^{\mathrm{a}}$ & $0.833^{\mathrm{c}}$ & $0.777^{\mathrm{c}}$ & - \\
Tyramine & $0.963^{\mathrm{a}}$ & $0.451^{\mathrm{ns}}$ & - & - \\
BAI & $0.978^{\mathrm{a}}$ & $0.874^{\mathrm{b}}$ & - & - \\
\hline
\end{tabular}

${ }^{a}(p<0.001)$

${ }^{b}(p<0.01)$

${ }^{c}(p<0.05)$

${ }^{n s}$ not significant 
2. Saaid M, Saad B, Hashim NH, Ali ASM, Saleh MI. Determination of biogenic amines in selected Malaysian food. Food Chem 2009;113:1356-62.

3. Shalaby AR. Significance of biogenic amines to food safety and human health. Food Res Int 1996;29:675-90.

4. Kim MK, Mah JH, Hwang HJ. Biogenic amine formation and bacterial contribution in fish, squid and shellfish. Food Chem 2009;116:87-95.

5. Paarup T, Sanchez JA, Moral A, Christensen H, Bisgaard M, Gram L. Sensory, chemical and bacteriological changes during storage of iced squid (Todaropsis eblanae). J Appl Microbiol 2002;92:941-50.

6. Benner RA Jr, Staruszkiewicz WF, Rogers PL, Otwell S. Evaluation of putrescine, cadaverine, and indole as chemical indicators of decomposition in penaeid shrimp. J Food Sci 2003;68:2178-85.

7. Lakshmanan R, Jeya Shakila J, Jeyasekaran G. Survival of amine-forming bacteria during the ice storage of fish and shrimp. Food Microbiol 2002;19:617-25.

8. Goulas AE, Chouliara I, Nessi E, Kontominas MG, Savvaidis IN. Microbiological, biochemical and sensory assessment of mussels (Mytilus galloprovincialis) stored under modified atmosphere packaging. J Appl Microbiol 2005;98:752-60.

9. Losada V, Rodriguez O, Miranda JM, Barros-Velázquez J, Aubourg SP. Development of different damage pathways in Norway lobster (Nephrops norvegicus) stored under different chilling systems. J Sci Food Agric 2006;86:1552-8.

10. Pinto A, Ciccarese G, Corato R, Novello L, Terio V. Detection of pathogenic Vibrio parahaemolyticus in southern Italian shellfish. Food Control 2008;19:1037-41.

11. Lougovois VP, Kolovou MK, Savvaidis IN, Kontominas MG. Spoilage potential of ice-stored whole musky octopus (Eledone moschata). Int J Food Sci Technol 2008;43:1286-94.

12. Sullivan Jr JD, Ellis PC, Lee RG, Combs Jr WS, Watson SW Comparison of the Limulus Amoebocyte lysate test with plate counts and chemical analyses for assessment of the quality of lean fish. Appl Environ Microbiol 1983;45:720-2.

13. Prester Lj, Macan J, Varnai VM, Orct T, Vukušić J, Kipčić D. Endotoxin and biogenic amine levels in Atlantic mackerel (Scomber scombrus), sardine (Sardina pilchardus) and Mediterranean hake (Merluccius merluccius) stored at $22{ }^{\circ} \mathrm{C}$. Food Add Contam 2009;26:355-62.

14. Siragusa GR, Kang DH, Cutter CN. Monitoring the microbial contamination of beef carcass tissue with a rapid chromogenic Limulus amoebocyte lysate endpoint assay. Lett Appl Microbiol 2000;31:178-83.

15. Commission Regulation (EC) No 2073/2005 of 15 November 2005 on microbiological criteria for foodstuffs [displayed 8 November 2010]. Available at http://www.fsai. ie/uploadedFiles/Reg2073_2005(1).pdf.

16. Shakila RJ, Vasundhara TS, Kumudavally KV. A comparison of the TLC-densitometry and HPLC method for the determination of biogenic amines in fish and fishery products. Food Chem 2001;75:255-9.

17. Valls JE, Bello RA, Kodaira MS. Semiquantitative analysis by thin-layer chromatography (TLC) of biogenic amines in dried, salted and canned fish products. J Food Qual 2002;25:165-76.

18. Lieber ER, Taylor SL. Thin-layer chromatographic screening methods for histamine in tuna fish. J Chromatogr 1978;153:143-52.
19. Food and Drug Administration (FDA). Decomposition and histamine: raw, frozen tuna and mahi-mahi, canned tuna, and related species, revised compliance policy guide, availability. Fed Reg 1995;49:39754-6.

20. Silla Santos MH. Biogenic amines: Their importance in foods. Int J Food Microbiol 1996;29:213-31.

21. Yamanaka H, Shiomi K, Kikuchi T. Agmatine as a potential index for freshness of common squid (Todarodes pacificus). J Food Sci 1987:52:936-8.

22. Ruiz-Capillas C, Moral A, Morales J, Montero P. Characterization of non-protein nitrogen in the Cephalopods volador (Illex coindetii), pota (Todaropsis eblanae) and octopus (Eledone cirrhosa). Food Chem 2002;76:165-72.

23. Mietz JL, Karmas E. Polyamines and histamine content in rockfish, salmon, lobster and shrimp as an indicator of decomposition. J Assoc Off Anal Chem 1978;61:139-45.

24. Shakila RJ, Vasundhara TS, Rao DV. Rapid quality assessment of shrimps during storage by monitoring amines. J Food Sci Technol (Mysore) 1995;32:310-4.

25. Zhao QX, Xu J, Xue CH, Sheng WJ, Gao RC, Xue Y, Li ZJ. Determination of biogenic amines in squid and white prawn by high-performance liquid chromatography with postcolumn derivatization. J Agric Food Chem 2007;55:3083-8.

26. Maintz L, Novak N. Histamine and histamine intolerance. Am J Clin Nutr 2007;85:1185-96.

27. Vickerstaff Joneja JM, Cabrini Carmona S. Outcome of a histamine-restricted diet based on chart audit. J Nutr Environ Med 2001;11:249-62.

28. Auerswald L, Morren C, Lopata AL. Histamine levels in seventeen species of fresh and processed South African seafood. Food Chem 2006;98:231-9.

29. Erkan N. Changes in quality characteristics during cold storage of shucked mussels (Mytilus galloprovincialis) and selected chemical decomposition indicators. J Sci Food Agric 2005;85:2625-30.

30. Mackie IM, Pirie L, Ritchie AH, Yamanaka H. The formation of non-volatile amines in relation to concentrations of free basic amino acids during postmortem storage of the muscle of scallop (Pecten maximus), herring (Clupea harengus) and mackerel (Scomber scombrus). Food Chem 1997;60:2915 .

31. Visciano P, Campana G, Annunziata L, Vergara A, Ianieri A. Effect of storage temperature on histamine formation in Sardina Pilchardus and Engraulis Encrasicolus after catch. J Food Biochem 2007;31:577-88.

32. Du WX, Lin CM, Phu AT, Cornell JA, Marshall MR, Wei CI. Development of biogenic amines in yellowfin tuna (Thunnus albacares): Effect of storage and correlation with decarboxylase-positive bacterial flora. J Food Sci 2002;67:292-301.

33. Veciana-Nogués MT, Mariné-Font A, Vidal-Carou MC. Biogenic amines as hygienic quality indicators of tuna. Relationship with microbial counts, ATP-related compound, volatile amines, and organoleptic changes. J Agric Food Chem 1997;45:2036-41.

34. Pons-Sánchez-Cascado S, Veciana-Nogués MT, Bover-Cid S, Mariné-Font A, Vidal-Carou MC. Use of volatile and non-volatile amines to evaluate the freshness of anchovies stored in ice. J Sci Food Agric 2006;86:699-705.

35. Křižek M, Pavliček T, Vácha F. Formation of selected biogenic amines in carp meat. J Sci Food Agric 2002;82:108893. 
36. Chytiri S, Paleologos E, Savvaidis I, Kontominas MG. Relation of biogenic amines with microbial and sensory changes of whole and filleted freshwater rainbow trout (Onchorynchus mykiss) stored on ice. J Food Prot 2004;67:960-5.

37. Yamanaka H, Shiomi K, Kikuchi T. Cadaverine as a potential index for decomposition of salmonoid fishes. J Food Hyg Soc Jpn 1989;30:170-4.
38. Baixas-Nogueras S, Bover-Cid S, Vidal-Carou MC, Veciana-Nogués MT. Volatile and nonvolatile amines in Mediterranean hake as a function of their storage temperature. J Food Sci 2001;66:83-8. 


\section{Sažetak \\ ODREĐIVANJE BIOGENIH AMINA I ENDOTOKSINA U LIGNJI, MUZGAVCU, ŠKAMPIMA I DAGNJI POHRANJENIMA NA SOBNOJ TEMPERATURI}

Istraživanja o pokazateljima kontaminacije mekušaca i člankonožaca iz mediteranskih zemalja su rijetka. Cilj ovoga rada bio je ispitivanje koncentracije endotoksina i četiriju biogenih amina (histamin, putrescin, tiramin i kadaverin) u lignji (Loligo subulata, Lamarck, 1798), muzgavcu (Eledone moschata, Lamarck, 1798), škampima (Nephrops norvegicus, Linnaeus, 1758) i dagnji (Mytilus galloprovincialis, Lamarck, 1819) iz Jadranskog mora koji su bili pohranjeni na sobnoj temperaturi tijekom $24 \mathrm{~h}$. Količina endotoksina u svježoj lignji, škampima i dagnji $\left(<1 \mathrm{EU} \mathrm{mg}^{-1}\right)$ upućuje na njihovu dobru mikrobiološku kvalitetu. Visoka korelacija ustanovljena je između indeksa biogenih amina (suma histamina, putrescina, tiramina i kadaverina) $\mathrm{i}$ endotoksina u lignji $(\mathrm{r}=0,978, \mathrm{p}<0,001)$ i muzgavcu $(\mathrm{r}=0,874, \mathrm{p}<0,01)$. Također je ustanovljena visoka korelacija između endotoksina i putrescina u škampima $(r=0,777, p<0,05)$. Najveća razina endotoksina (povezana s porastom histamina) ustanovljena je kod dagnje. U zaključku, porast biogenih amina je species-specifičan. Analiza endotoksina mogla bi se primijeniti kao brza metoda za određivanje mikrobiološke ispravnosti mekušaca i člankonožaca.

KLJUČNE RIJEČI: histamin, tiramin, putrescin, kadaverin, glavonošci, člankonošci, školjkaši, sigurnost hrane, kontaminacija, Loligo subulata, Eledone moschata, Nephrops norvegicus, Mytilus galloprovincialis

\section{CORRESPONDING AUTHOR:}

\section{Ljerka Prester}

Institute for Medical Research and Occupational Health

Ksaverska c. 2, HR-10001 Zagreb, Croatia

E-mail:prester@imi.hr 